\title{
Digital initiatives invite a new conception of academic librarians
}

\author{
Amanda Y. Makula \\ University of San Diego, San Diego, CA
}

Abstract: Academic digital librarian positions are on the rise, and the interdepartmental and crossinstitutional collaborations they build signal a paradigm shift for the profession.

Author Bio: Amanda Y. Makula is the Digital Initiatives Librarian at the University of San Diego.

Keywords: digital librarians, academic librarians, higher education, campus, collaboration, service, partnership, paradigm shift

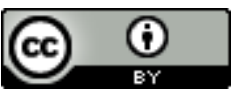

This is an Open Access article distributed under the terms of the Creative Commons Attribution 4.0 International License (http://creativecommons.org/licenses/by/4.0), which permits unrestricted use, distribution, and reproduction in any medium, provided the original work is properly cited. 
Type “digital” into ALA JOBLIST's keyword search (joblist.ala.org) and the number of results reflect a sizeable share of the total posted positions (roughly $40 \%$ at this writing). Limit your search to academic/research libraries and the proportion increases (now 55\%). Titles like "Digital Scholarship Futurist," "Digital Asset Management Coordinator," "Data Services Librarian," "Archivist for Discovery and Access," "Institutional Repository Librarian" and "Research Librarian for Digital Humanities \& History" fill the screen.

I first noticed the popularity of positions with a strong digital component - many of which did not exist a decade ago - while conducting a job search of my own. For twelve years, I worked as a research and instruction librarian at a liberal arts college. I loved the close interaction with students, faculty, and library colleagues. When my library launched an institutional repository and I volunteered to take the lead, I discovered a new passion: curating, sharing, and preserving the institution's history and scholarship in an open access environment.

Now, a year into a new position as digital initiatives librarian, what stands out to me most about this line of work is not what I originally expected to find. The technological component - trying to keep abreast of new tools and how to utilize them productively - certainly looms large. It is the human dimension, however, that truly defines this emerging profession: specifically, the way in which the work intersects with nearly every other activity in the academic library, as well as the institution more broadly, and how it promises to transform work previously confined to a single realm into a collaborative, interdepartmental, cross-institutional endeavor.

In order to promote discoverability of the digital objects they curate, these digital librarians (as I will refer to them) invite catalogers to weigh in with metadata expertise. They work with systems staff to integrate digitally-held objects into the online catalog, or partner with access services on copyright questions and intellectual property education. In many cases, they consult with colleagues in archives 
and special collections to spotlight unique holdings via digital exhibits. Through close collaboration with teaching, reference, and liaison librarians, they explore the intersection of information literacy and scholarly communication, asking how to engage students and faculty on issues surrounding open access, strengths and criticisms of the peer review model, the role of traditional and alternative metrics, and what it means to move from consumer to producer in a knowledge economy.

Beyond the walls of the library, digital librarians engage in collaboration across the institution. They work directly with faculty, administrators, and students on projects involving library publishing, data management, or the digital humanities. They seek out members of the institutional marketing team, admissions, or alumni relations in order to communicate the ways in which the institutional repository can support recruitment, giving campaigns, and engagement with the local community. They solicit historical artifacts (newsletters, meeting minutes, photographs, etc.) from offices across campus in order to facilitate their digital preservation and access.

Are digital librarians the only librarians taking this broad view of the educational enterprise and looking for ways to forge and nurture partnerships? No, of course not. Librarians of all stripes have long been involved in collaborative initiatives across campus, such as serving on institution-wide committees, teaching course-integrated or credit-bearing information literacy classes, and spearheading campus events. Rather, I argue that the work of digital librarians takes this outreach and relationship-building to new heights. For one thing, the job itself requires it. They simply cannot successfully carry out their charge(s) otherwise. How does one publish an open access journal without coordinating with its content producers and/or editors? Or develop a digital archive for university publications without enlisting the participation of that office? Further, the prevalence of digital librarian positions means more people are entering the field, whether fresh from graduate school or as mid-career transplants; more people in the field means greater librarian engagement with units across 
campus - in some cases, units that have never before interacted with a librarian. As digital librarianship continues to grow and take root, the academic community gains an increased awareness of librarians' expertise, a greater appreciation for their contributions, and a new expectation of their involvement. Will these changes in our work - and in how others view us - induce a fundamental change in how we see ourselves? Librarians have long self-identified as service providers, but the one-directional, transactional quality of providing service does not accurately convey the dynamic interplay that occurs with cross-institutional collaboration. We need a new paradigm that reflects this distinction. Partnership represents an ongoing exchange marked by active communication, negotiation, respect, and equality. Defining ourselves as partners better captures what we truly do. It articulates our role, our agency, and our value within the scholarly community. A partnership model has the potential to transform the place of the librarian - digital or otherwise - within the academy. When we embrace it, we assert how what we do connects to the larger story of the institution, and how, as true partners, we are co-authors of that narrative. 